\title{
Strong Employment, Low Inflation: How Has the US Economy Done So Well?
}

\author{
ReBeCCA M. BLANK \\ School of Public Policy \\ University of Michigan \\ Ann Arbor, Michigan
}

Cet article passe en revue les nouvelles économiques favorables aux États-Unis durant les années 90, caractérisées par une croissance économique continue avec un faible taux de chômage et une faible inflation. Cet échange chômage-inflation favorable a été rendue possible, en partie, par de nombreux facteurs qui ont gardé l'inflation des prix faible. De plus, de nombreux changements dans le marché du travail ont permi à la production (ainsi qu'au niveau d'emploi) de croître sans une inflation des salaires. Cet article explore les nombreuses théories se penchant sur les chances selon lesquelles ces tendances vont se poursuivre. La dernière section contient une discussion sur quelques issues politiques se dégageant de cette croissance actuelle.

This paper reviews the strong economic news from the United States over the 1990s, with continuing economic growth in the presence of low unemployment and low inflation. This favourable unemployment-inflation trade-off has been possible in part because of a series of factors that kept price inflation low. In addition, a number of labour market changes have also allowed output (and employment) to grow without wage inflation. The paper explores a variety of theories about the long-run prospects for these trends to continue. The final section discusses some policy issues raised by this ongoing expansion.

$\mathrm{I}$

n December 1998, the United States entered its longest peace-time expansion. If this expansion continues through February 2000 (and that appears entirely likely) the economy will break all records and enter the longest expansion in US history.

\section{LoTs of Good News}

The record of economic accomplishment over the 1990s is impressive. Figure 1 shows the strong re- cent gross domestic product (GDP) growth, with rates that average above 4 percent in every year since 1991. Along with strong overall growth has come strong employment growth, with over 20 million new jobs created during the expansion. Unemployment is at its lowest level since the 1960s, hitting 4.1 percent in the fall of 1999 (see Figure 2). Unemployment rates have been at or below 5 percent since April 1997 and at or below 4.5 percent since April 1998. Unemployment has fallen particularly far among historically disadvantaged groups, with 
FIGURE 1

Real GDP

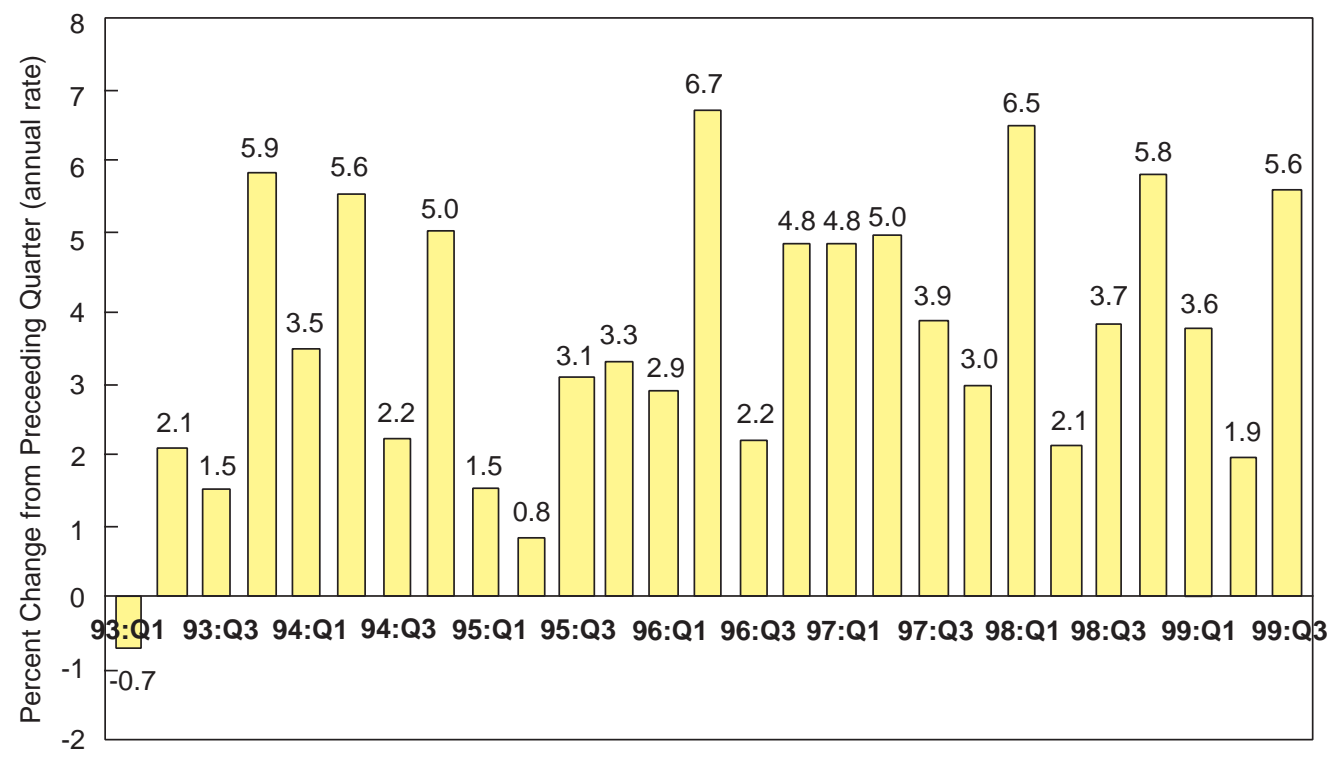

Source: Department of Commerce (Bureau of Economic Analysis).

\section{FIGURE 2}

Civilian Unemployment Rate

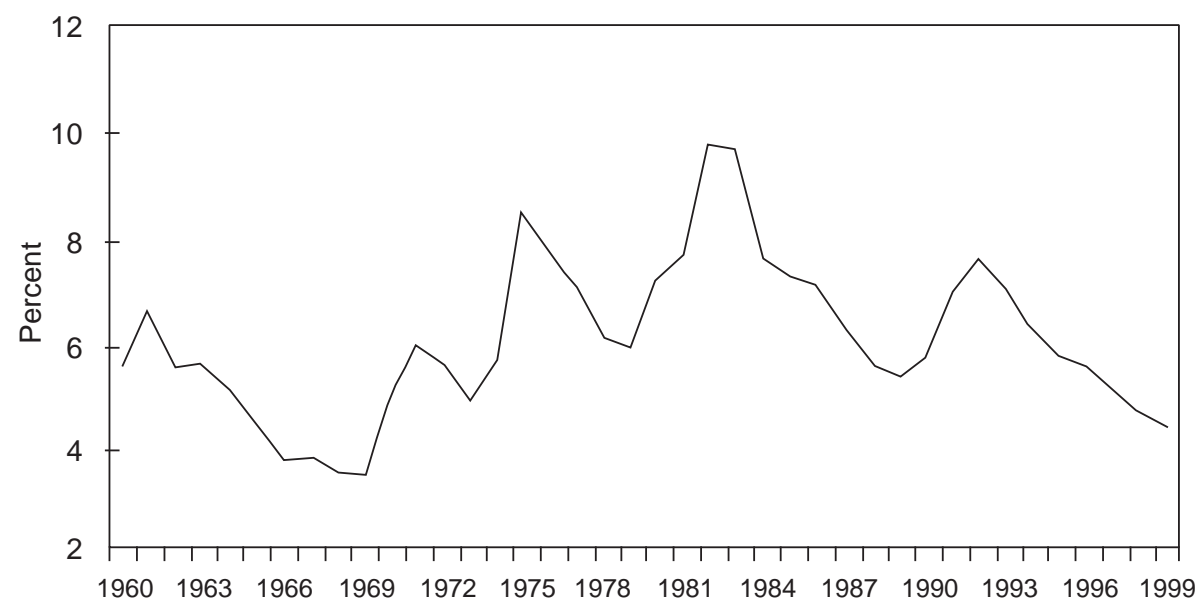

Source: Department of Labor (Bureau of Labor Statistics). 
very low rates among Hispanic and black workers, and among workers with less than a high school degree.

At the same time, inflation remains low, as Figure 3 indicates. The GDP deflator rose less than 1 percent in 1998 and less than 2 percent in the two preceding years. This low and stable inflation rate has allowed the Federal Reserve to maintain generally low interest rates for an extended period of time. The result has been a healthy increase in investment. Figure 4 indicates the underlying components of GDP change in the three long expansions of the 1960s, the 1980s, and the 1990s. All three expansions showed strong consumption growth. Investment growth has been much more important in the 1990s, however. Government spending has had virtually no expansionary effect over the 1990s, in striking contrast to the two earlier expansions where increased government deficits were a major driver of economic growth. With the Asian financial cri- sis, net exports have also had a stronger negative impact in the 1990s than in earlier expansions.

The labour market has been the source of some of the best news in recent years. After almost 20 years of rising inequality and declining wages among less-skilled workers, the current expansion has reversed this trend. As Figures 5 and 6 show, wages among both men and women and among whites, blacks, and Hispanics are rising. Furthermore, wages are rising across the wage distribution. The Council of Economic Advisers (1999) indicates that real wages of men in the tenth decile of the wage distribution have risen by 6 percent since 1993 , while women's real wages have risen by 5 percent. While these recent patterns are not yet strong enough to fully reverse the impact on the last 20 years of wage declines, at least wages are moving up for all workers. It is worth noting that US wage inequality has not declined in the 1990s, although the increase in inequality has stopped. Essentially, wages are now

\section{FIGURE 3}

Consumer Price Inflation

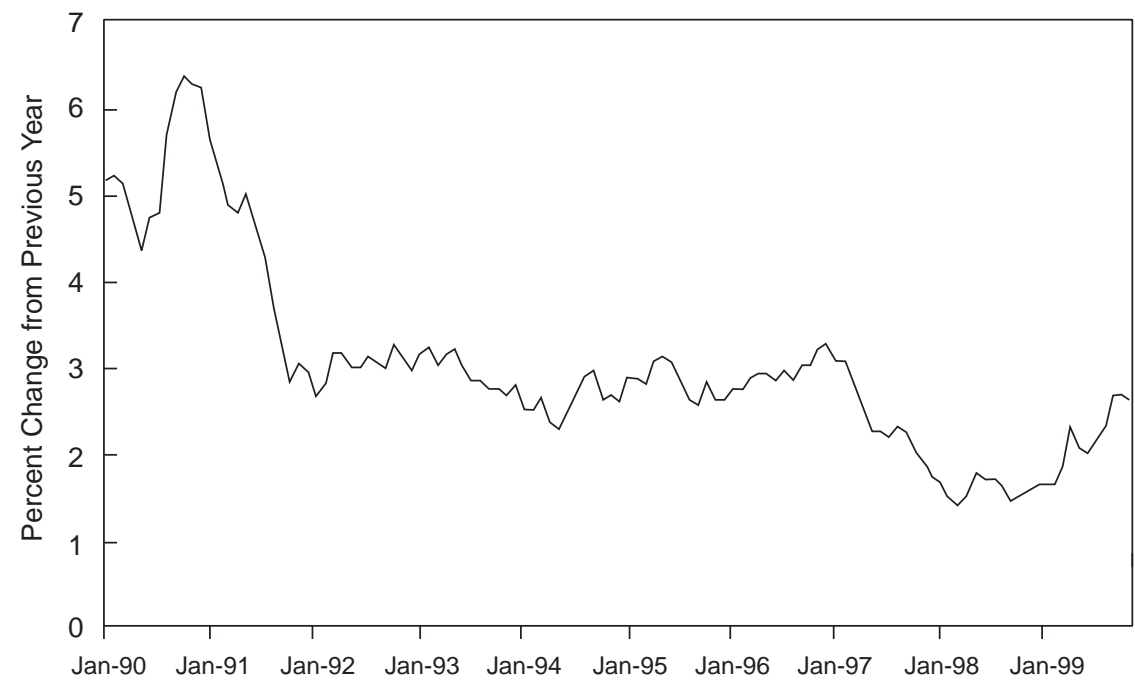

Source: Department of Labor (Bureau of Labor Statistics). 
FIGURE 4

Contributions to Growth in Three Long Expansions

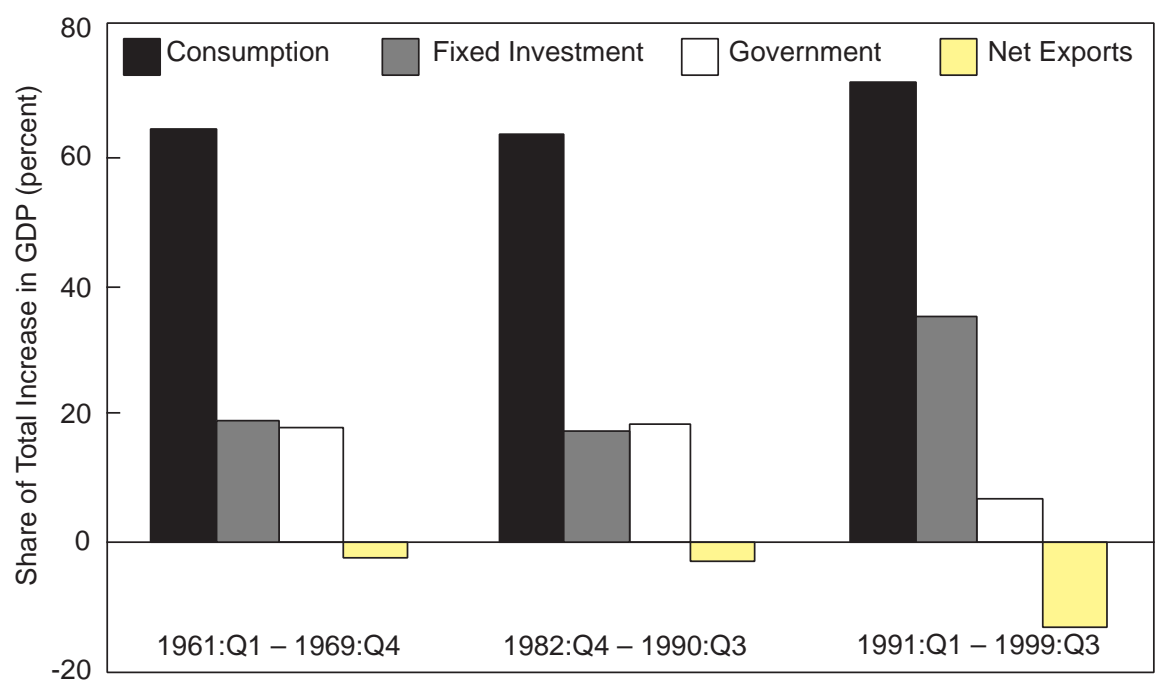

Source: Department of Commerce (Bureau of Economic Analysis) and National Bureau of Economic Research.

FIGURE 5

Median Hourly Wages of Men Aged 16 and Over, by Race and Ethnicity

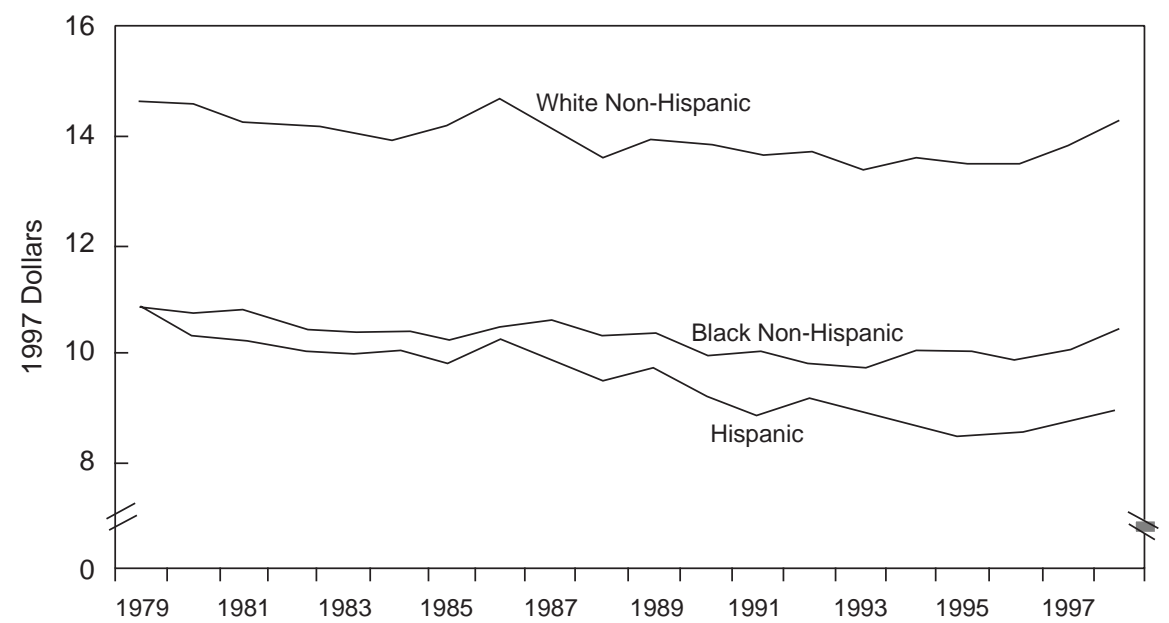

Note: Sample includes part-time as well as full-time workers.

Source: Council of Economic Advisers tabulations of Current Population Survey data. 
FIGURE 6

Median Hourly Wages of Women Aged 16 and Over, by Race and Ethnicity

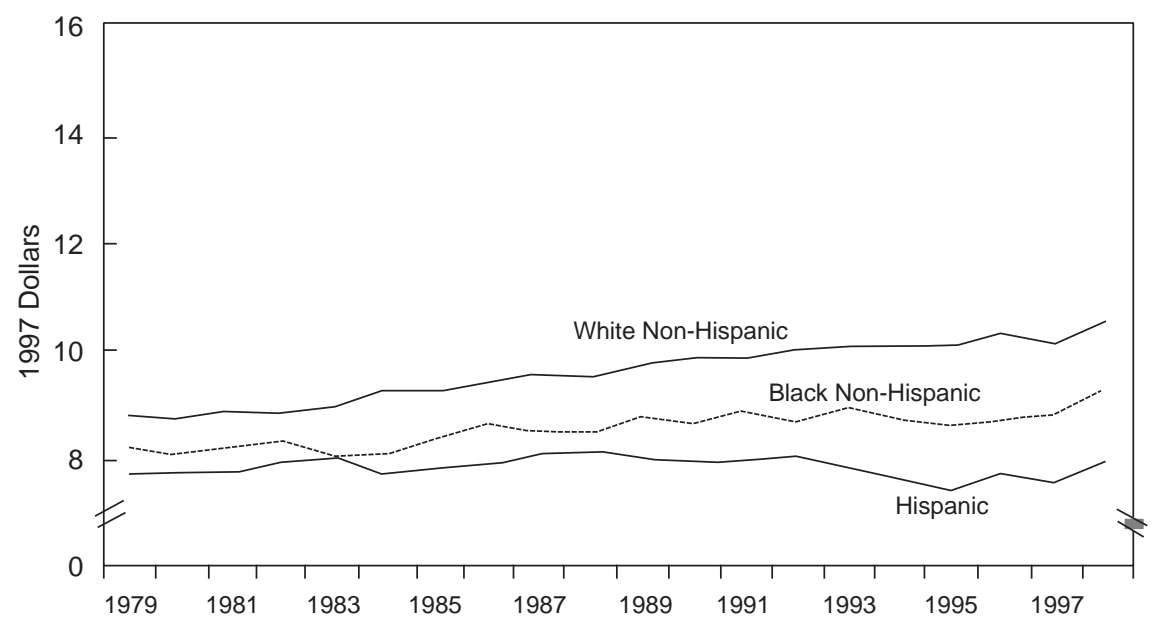

Note: Sample includes part-time as well as full-time workers.

Source: Council of Economic Advisers tabulations of Current Population Survey data.

FIGURE 7

Growth in Real Family Income

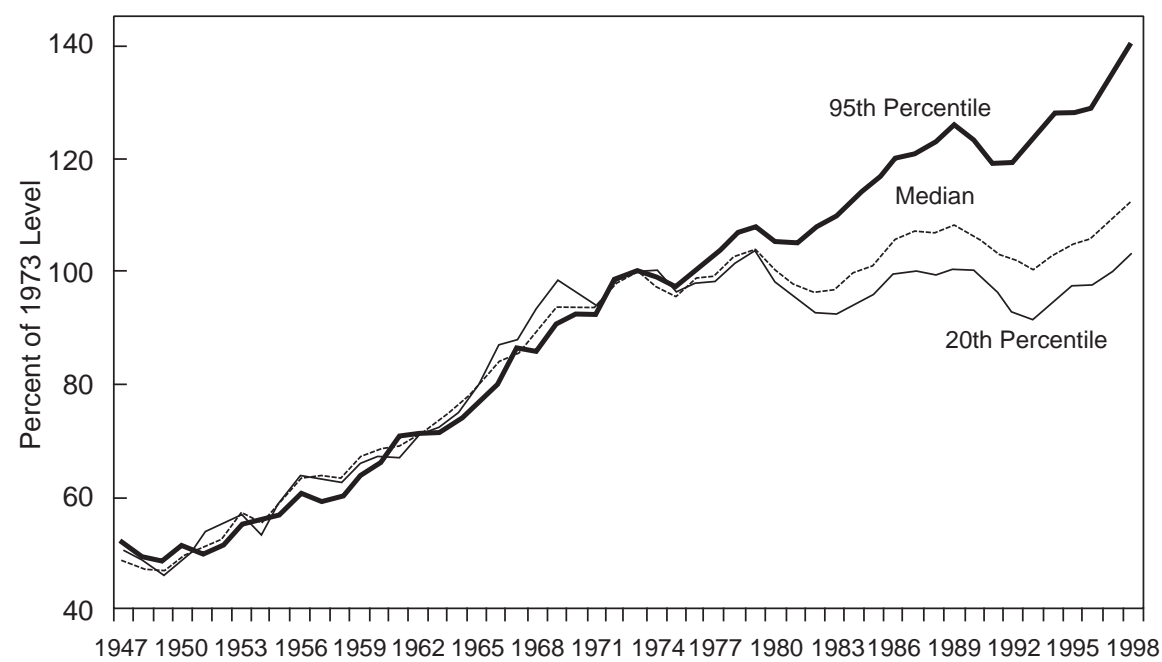

Source: Department of Commerce (Bureau of the Census). 
rising rapidly at both the top and the bottom, maintaining differentials between more and less-skilled workers even as real wages rise across all groups.

Strong employment growth combined with real wage growth has produced noticeable growth in real family income. Figure 7 shows sharp increases in real family income since 1991, following a steep decline in 1990-91. In 1998 family income hit an all-time high, above its previous peak in 1989. Again, this income growth is occurring across the income distribution, with incomes at the $20^{\text {th }}$ and the $80^{\text {th }}$ percentiles both rising at about the same rate. As Figure 7 indicates, incomes among families at the top $95^{\text {th }}$ percentile continue to grow faster than the median.

In short, in this expansion we have achieved an economy with stable levels of inflation and steadily increasing employment. This combined good news on inflation and employment has continued for three to four years, with little sign of abating. The data defy our earlier Phillips curves estimates; few economists would have predicted in 1990 that the United States would have been able to accomplish such low levels of unemployment and inflation over such a sustained period.

\section{How DiD IT HAPPEN?}

There are at least two simultaneous forces driving these successful inflation/employment effects in the US. First, a variety of short-run events have kept price inflation low; second, certain short-run changes in the labour market have moderated wage growth in the midst of employment expansion. At least some observers argue that a set of long-term structural economic changes are occurring in the US economy, and these so-called "short-run" phenomena are likely to continue for some time. Let me describe each of these arguments, in turn.

\section{Price Inflation Has Stayed Low}

A set of widely agreed-upon factors have kept price inflation at a relatively low level for the last several years. While many of these factors are likely to be short term in nature, some of them could continue in the near future.

First, the Asian financial crisis has produced weak import and export prices. This has kept the prices in the traded sector of the economy low and stable.

Second, there was a sharp fall in oil prices over the 1990s, in part because of weak demand in Asia. Even though recent oil price levels have gone up again, we are still at relatively low levels historically.

Third, computer equipment prices continue to fall rapidly. Even though this is only a small part of the overall economy, it is growing rapidly. And even quite small sectors that experience price declines in the three digits can have an impact on aggregate prices.

Fourth, health costs have shown only moderate growth in recent years, after more than a decade of very high price increases. Many observers attribute this to a one-time shift in the US health-care industry to health management organizations (HMOs) and managed care.

Fifth, the United States has made a series of methodological adjustments to the Consumer Price Index (CPI) over the past several years. Designed to provide an improved measure of prices, the net effect has been to lower the overall CPI by about half of a percentage point relative to where it would have been in the absence of these changes.

All of these factors have had an impact on the Consumer Price Index, allowing the US to maintain a lower inflation rate than might be expected at current levels of unemployment. How long most of them will continue is currently unclear.

\section{Changes in the Labor Market Have also Shifted the Inflation-Unemployment Trade-off} Three major factors in the labour market have also worked to moderate inflationary wage increases, and 
have helped shift the Phillips curve to the left, at least in the near term.

First, the demographic mix of the US workforce has shifted in recent decades. The baby boom generation is currently in its prime earning years, a period when most people are stably employed. Conversely, a smaller share of the workforce is in their teenage or young adult years, a period when unemployment tends to be more frequent as workers move in and out of employment. Katz and Krueger (1999) estimate that about one-third of the decline in the NAIRU is due to these demographic changes.

Second, the United States has experienced remarkably high productivity growth in recent years. Since 1988, productivity growth in the US has averaged 1.8 percent. It has been well above this rate in the last four years, as Figure 8 indicates. While there is some cyclicality to productivity, recent productivity numbers have been higher than historical models would predict at this point in the cycle. Of course, higher productivity means that workers can receive real wage gains without inflationary pressures. A key question is whether this productivity surge is a short-run phenomenon or whether it is likely to continue in the foreseeable future.

Third, there has been a strong surge in labour force participation among mothers, especially single mothers with young children. Figure 9 indicates that labour force participation rates among single women without children have been flat, but they have grown steadily among married women with children, and grown even faster among single mothers. These increases in labour force participation are even larger for mothers with children under age six. This has allowed employment to expand through an increase in labour force participation, lessening inflationary wage pressures.

These labour force expansions among mothers are partially due to the strong economy and the growth

\section{FIGURE 8}

Productivity Growth, Non-farm Business

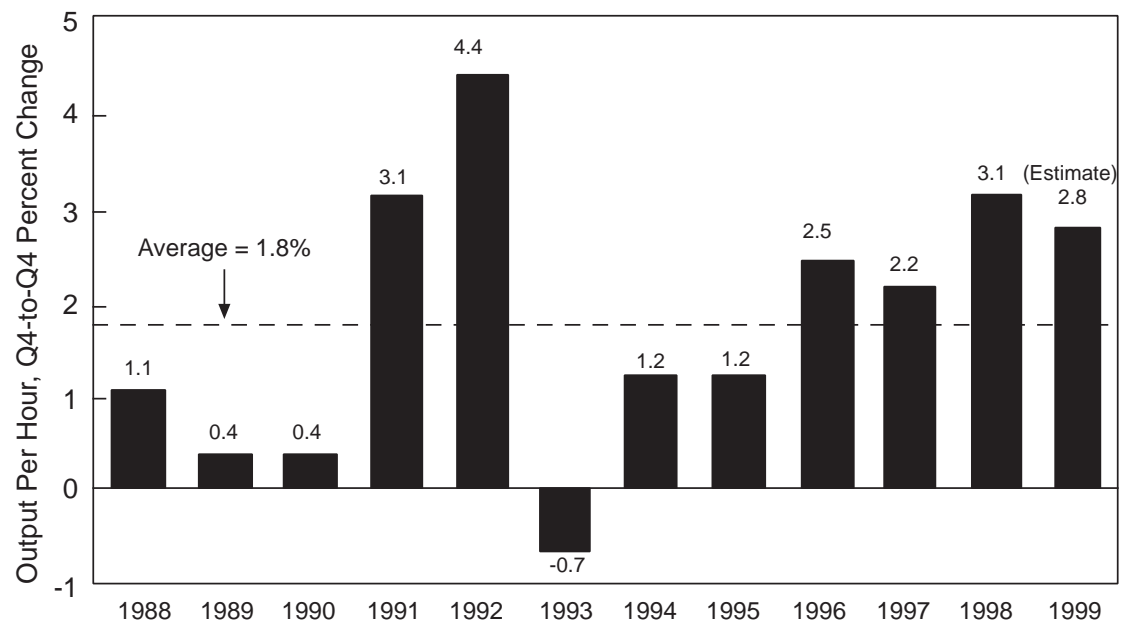

Note: Estimate for 1999 based on first three quarters.

Source: Department of Labor (Bureau of Labor Statistics). 


\section{FIGURE 9}

Labour Force Participation of Women

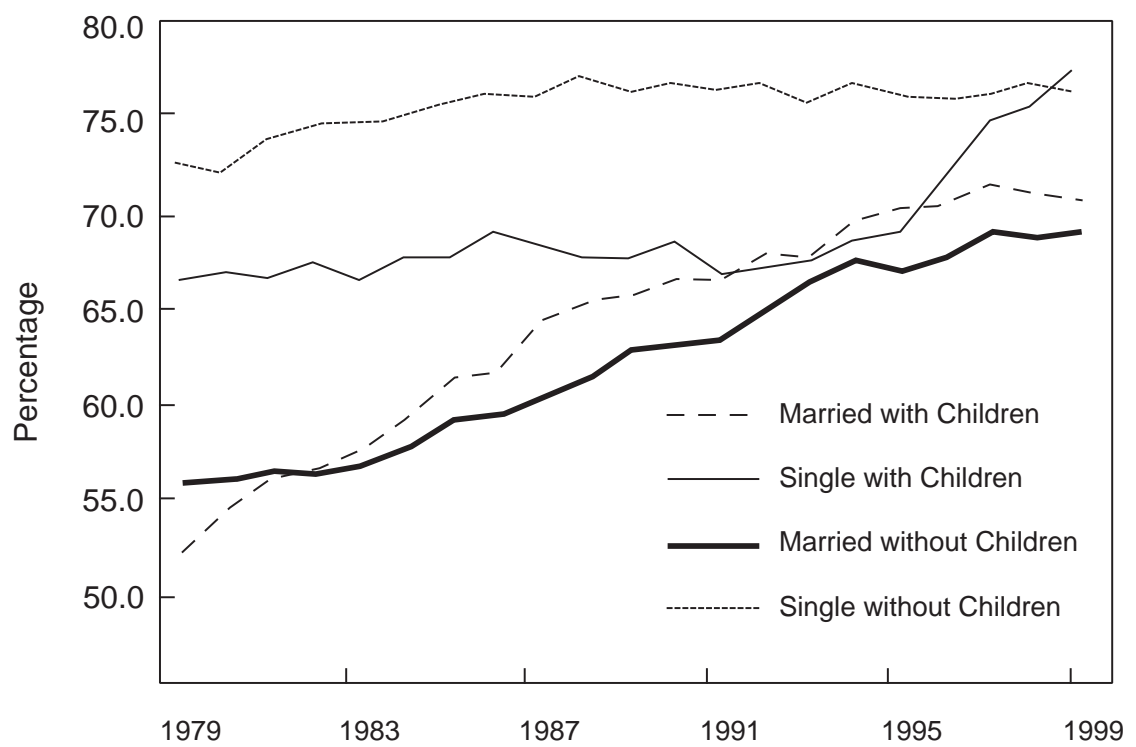

Source: Tabulated by author from Current Population Survey data.

in employment opportunities. But there is also substantial evidence that they are due to other policy changes as well. Public assistance programs in the United States underwent major reforms in the 1990s, with greater limits on benefit eligibility and strong work requirements for recipients. At the same time, there was a major expansion in the returns to work among less-skilled workers. The increases in labour force participation among single women have been highly correlated with the increases in the Earned Income Tax Credit (EITC), a wage subsidy available through the US tax system to workers in lowincome families. Meyer and Rosenbaum (1999) estimate that about half of the labour force increases among single mothers between 1984 and 1996 are due to the EITC expansions.

Table 1 provides further documentation of the increased returns to work among less-skilled US workers. The minimum wage rose 17 percent between 1989 and 1998 (in 1998 dollars). The maximum EITC subsidy rose 90 percent for single mothers with one child and a whopping 214 percent for single mothers with two or more children. As a result, a single mother working full-time at the minimum wage in 1989 and 1998 would have experienced a 26 percent increase in real earning power if she had one child, and a 40 percent increase with two or more children. These are remarkably large increases in the returns to work over a relatively short period of time, and one would expect the result to be increases in labour supply among lowwage workers. Fortuitously, these policy changes occurred just as employment demand was rising in the macroeconomy, and the EITC increases ultimately worked to lessen wage inflation by inducing a greater increase in labour market participation than the economic expansion alone would have generated. 
TABLE 1

Effects of Changing Policy on Earnings of Single Mothers (All numbers in 1998 dollars)

\begin{tabular}{lccr}
\hline & 1989 & 1998 & $\begin{array}{r}\text { Percent } \\
\text { Change }\end{array}$ \\
\hline Minimum Wage & $\$ 4.41$ & $\$ 5.15$ & 16.8 \\
Maximum ElTC Subsidy & & & \\
$\quad$ Single mother (1 child) & $\$ 1,197$ & $\$ 2,271$ & 89.7 \\
$\quad$ Single mother (2 children) & $\$ 1,197$ & $\$ 3,756$ & \\
& & & \\
Earnings & & & \\
$\quad$ Single mother (1 child) & $\$ 9,856$ & $\$ 12,571$ & \\
$\quad$ Single mother (2 children) & $\$ 9,856$ & & \\
Ratio of Earnings to US Poverty Line & & 14,056 & \\
$\quad$ Single mother (1 child) & & & \\
$\quad$ Single mother (2 children) & 0.89 & 1.03 & \\
\hline
\end{tabular}

Note: ${ }^{1}$ Single mother working full-time at minimum wage.

\section{What about the Long-Run Prospects?}

The big question is "How permanent are any of these effects?" If we have managed to improve the inflation-unemployment trade-off in the long run, then we should be much more optimistic about the future prospects for long-term higher rates of economic growth. At least some observers have argued that this is likely, based on four general arguments. I should note that I consider all four of these arguments unproven hypotheses. It will be some time before we can confidently declare that there has been a long-term shift in these factors.

Theory 1: Job matching has improved, smoothing workers' transition into the labour market and thereby permanently lowering unemployment rates. The primary story here is that the rise of new information technologies (especially the Internet) is allowing employers and workers to exchange more and faster information and thereby make faster and better matches. There is little hard evidence for this, other than evidence on the rapid growth in the Internet as a tool for employment search. It is primarily short-run unemployment spells that have declined (long-term unemployment remains at about the same level now as five or six years ago), which is consistent with a story in which motivated workers are able to find new employment more quickly than in the past. Further evidence and research on the role of new technologies in hiring and job search behaviour is necessary before this hypothesis can be considered proved. I might also note that, even if true, improvements in job matching are unlikely to have more than a small marginal effect on underlying unemployment rates.

Theory 2: Worker demands have abated due to changes in the structure of employment, so that inflationary wage pressures are lower at this point in the cycle than in past economic expansions. There are three versions of this story. Version one argues that the increasing globalization of the US economy has brought US workers into greater competition 
with labour in other countries, changing the way that employers utilize labour and heightening workers' own sense of insecurity. Version two focuses on the growth in contingent and non-standard work contracts among US workers (perhaps due to greater global competition), and emphasizes the resulting worker uncertainty when more and more jobs are "contracted out" by firms. Version three points to the decline in unionization in the US economy, and argues that both the direct and indirect (demonstration) effects of unions on worker-employer negotiations have declined, which may have permanently weakened workers' bargaining power.

While there is evidence consistent with all of these stories - the traded sector of the US economy has expanded, contingent work has grown, and unionization continues to decline - there is little evidence on the extent to which any of these factors have moderated wage demands. This theory suggests that one should see lower wage demands in the 1990s in industries that are heavily traded, that utilize a higher share of contingent workers, or that are less unionized. These are researchable questions that it would be interesting to explore.

Theory 3: Productivity is on a long-term higher trend. There are two versions of this story. Version one suggests that we mismeasure productivity so badly that true productivity growth is actually much higher than we know. Since the worse mismeasurement of productivity occurs in the most rapidly growing sector of the US economy, namely, the service sector, this undermeasurement problem should have become progressively worse over time.

Version two argues that the computer revolution will over time substantially raise worker productivity. In particular, as computers become much more user friendly, they should enhance not just the work of highly-skilled workers but should also increasingly complement the work of less-skilled workers. (Davis and Wessel 1998, provide one of the best statements of this argument.) This theory argues that the positive shock to productivity due to the wide- spread use of computers has just begun, with large future gains still to be experienced.

Theory 4: The sustained economic expansion of the 1990s will produce long-run positive hysteresis effects. Economists have argued that the high unemployment rates in Europe over the past two decades have been sustained in part due to hysteresis, that is, workers who leave the labour market become progressively less connected over time. Their skills may deteriorate and/or their preferences may shift so that they become less diligent at searching for work and find hanging out at home more enjoyable. The result is that a period of high and sustained unemployment may create a long-run, higher underlying, unemployment rate and a worse inflation/unemployment trade-off.

If this story makes sense for Europe in recent decades, then positive hysteresis effects should be occurring in the United States in the 1990s. Workers have been able to find employment more easily; not only has labour force participation risen, but spells of unemployment among those in the labour market have declined. The result should be a growth in worker skills due to increased experience. Workers may also become more "persistent workers," that is, as they learn about the labour market they develop a better sense of how to find and keep a job, as well as better "coping skills" that allow them to organize their life around work. (For instance, a single mother might develop ways to deal with child care when her child gets sick.) Even when unemployment rises and jobs become more scarce, employers might be more likely to keep a particular worker employed because of his or her greater experience, and workers might be more likely to search more diligently and more effectively for another job if they do become laid off. Under these circumstances, the high and sustained employment levels in the United States in the 1990s should mean that unemployment will not rise as quickly when an economic slowdown occurs.

The positive hysteresis is an interesting one that I fully believe occurs for some workers. I am, 
however, aware of no evidence that indicates what the magnitude of these effects might be. Further research on this topic would be highly useful.

\section{The Role of Policy}

Overall, the US macroeconomy is "caught" in a high-level equilibrium, which some have referred to as a virtuous cycle. Because this expansion seems stable and inflation is low, firms have raised investment. This increases productivity and lowers capacity utilization. This keeps inflation low and allows interest rates to remain low. This in turn generates more investment that keeps the process going.

This strong economic position is partly due to luck - for instance, the timing of the Asian slowdown for the US economy ended up being quite fortuitous - and partly due to the improved inflation/unemployment trade-off that exists at least in the short run.

But policy has also been important. As noted above, a variety of program changes aimed at lowincome families in the US have increased labour supply and improved the returns to work. The elimination of the US federal budget deficit has also played a key role in this expansion, enhancing the trust of the private sector that this expansion is sustainable and lowering their fears about future inflation. This deficit reduction was the explicit result of a commitment by the Clinton administration to enact and enforce budget discipline. Finally, the role of the Federal Reserve Bank has been highly important in keeping a steady hand on the money supply and maintaining relatively low interest rates. The trust the private sector has in Alan Greenspan's judgement been an important component of their overall trust in the stability of this expansion.

The opportunities provided by this very long and sustained economic expansion raise at last two further policy questions. First, can we do anything to keep this expansion going or to moderate the inevi- table slowdown when it comes? In my opinion, the most important policy issue for the federal government is to keep government deficits down and to deal wisely with the near-term budget surplus. We should invest now to minimize the inevitable problems that will be facing the US public pension and health-care system when today's baby boomers reach retirement age. The most responsible thing our government can do is to invest today's resources in a way that prepares for future high demands on the social security and medicare systems. This will help create long-term stability in the federal budget and to reduce future economic and political problems.

Education and training policies are also key to enhancing the prospect for long-run economic growth. This means maintaining and improving the quality of the public educational system available to children (tomorrow's workers) and of the education and job-training system available to current adults. This is a longterm agenda, which requires serious and coordinated efforts involving cities, states, and the federal government. But lowering the high school dropout rate and increasing educational opportunities should improve the skill level of current and future workers. This is the best way to guarantee that the currently higher productivity growth is sustained into the future.

A second major policy question is also important: What can we do to encourage widespread spillovers of our economic good fortune to historically disadvantaged areas and population groups, to assure that all groups of Americans benefit from the expansion? As we have moved further into this expansion, even quite low-skilled workers are experiencing declines in unemployment and increases in wages and family income. This is good news, but to assure that this trend continues there are at least two things we should do on the policy front. First, when labour is in short supply and employers are looking to non-traditional sources of labour, public policies should encourage employers to hire, train, and promote more low-skilled workers. For instance, subsidies to assist firms in providing training in English-as-a-second-language might help recent 
immigrants become more quickly integrated into the workforce. This is also the time to strongly enforce anti-discrimination laws, or to provide tax credits for hiring ex-public assistance recipients. All of these things can help historically disadvantaged workers gain from the economic expansion.

Second, we need to maintain our commitment to making work pay. The evidence suggests that the expansions in the EITC and the minimum wage occurred (quite serendipitously) at exactly the right time - the returns to work rose just when unemployment was at a 30-year low and work was more available than at any time in the recent past. Hence, the economic expansion and the policy changes reinforced each other, producing an explosion in labour force participation among less-skilled women, the group who were most likely to be outside the labour market and who were being increasingly pushed into work through welfare-to-work programs. Maintaining the real value of the wage subsidies and of the minimum wage is likely to be important if we want to keep these less-skilled workers employed and gaining job experience over time.

We do not yet fully understand our recent economic good fortune. Although I think we have ink- lings of some of the causes, it is difficult to sort out their relative importance. It will be an important long-term research agenda to do so. In the near term, we need to think creatively about policy so that we can strengthen and sustain the expansion, assure that more persons benefit from it, and use the opportunities it creates to improve the long-term skills and productivity of America's workforce. All of this will increase the likelihood of further real wage and income gains in the future.

\section{REFERENCES}

Council of Economic Advisers. 1999. Economic Report of the President, February 1999. Washington, DC: US Government Printing Office.

Davis, R. and D. Wessel. 1998. Prosperity: The Coming 20-Year Boom and What It Means to You. New York: Random House.

Katz, L.F. and A.B. Krueger. 1999. "The High-Pressure U.S. Labor Market of the 1990s," Brookings Papers on Economic Activity: Macroeconomics 1999:1. Washington, DC: The Brookings Institute.

Meyer, B.D. and D.T. Rosenbaum. 1999. "Welfare, the Earned Income Tax Credit, and the Labor Supply of Single Mothers," NBER Working Paper No. 7363. Cambridge, MA: National Bureau of Economic Research. 